\title{
School management in Serbia: Key aspects of its relation to school success ${ }^{*}$
}

\author{
Biljana Ratković Njegovan, Miloš Crnomarković***
}

This paper provides an overview of the present state of management of school systems in the Republic of Serbia, and discusses the issue of introducing professional school management. Present underdevelopment of school management reflects the fact that decision making on virtually all aspects of education are strictly state centralized. Education process also suffers from poor cooperation between parents and school. The survey was conducted in 12 schools in the Republic of Serbia, the participants being head teachers, teachers, school psychologists and pedagogical consultants. In this paper, the key research findings are discussed with respect to the necessity of efficient school development planning and allowing education staff greater control over the education process.

Dieser Artikel gibt einen Überblick über die derzeitige Situation der Verwaltung der Schulsysteme in der Republik Serbien. Die aktuelle Unterentwicklung des Schul-Managements reflektiert die Tatsache, dass die Entscheidungsfindung bezüglich fast aller Aspekte streng staatlich zentralisiert ist. Der Bildungsprozess leidet ebenfalls unter der schwachen Zusammenarbeit zwischen Schulen und Familien. Die Untersuchung wurde in 12 Schulen durchgeführt, die Befragten waren Schuldirektoren, Lehrer, Psychologen und Pädagogen. In diesem Artikel werden die Forschungsergebnisse diskutiert mit Bezug zur Notwendigkeit einer effizienten Schulentwicklungsplanung, die den Beschäftigten im Bildungswesen eine größere Kontrolle der Prozesse ermöglichen würde.

Keywords: school management, planning, decentralization, Republic of Serbia

Manuscript received: 19.06.11, accepted: 17.11 .11 (2 revisions)

** Biljana Ratković Njegovan, Ph.D., Assistant Professor, Department of Industrial Engineering and Management, University of Novi Sad, Serbia. Main research areas: School management. Coresponding address: biljananj@neobee.net.

Miloš Crnomarković, M.Sc., Head Teacher, Stara Pazova, Serbia. Main research areas: School management. 


\section{Introduction}

This paper aims to provide an insight into present possibilities for implementing the school management into primary and secondary state schools in Serbia. Beginning with an overview of several outstanding authors' approaches to and models of the concept and practice of school management, the authors sketch the framework for understanding the key obstacles to its implementing in Serbia, as well as the supportive incentives. The education system in Serbia for years now has been facing internal organizational issues and problems concerning the quality and quantity of the relationship between school and its social environment. Content and organizational changes imposed by scientific and technological innovations are accepted only partially and slowly since the classical organization of responsibilities is still dominant. The neo-liberal impulses in current education policy, with the radical "cut, cut, cut" imperative have only made this crisis deeper.

For a school to be successful it is, or will rather soon be very important to develop a quality school management as a set of interrelated activities of planning, organizing, governing, conducting and managing the educational organization. Therefore, the term pedagogical management is acceptable as well, since in the same context it stresses the priority of the core product: welleducated pupils/students. At present, however, due to centralized governing of schools through administrative and executive-professional bodies on the national, regional and local levels, school management is in practice lagging far behind the projected goals. Present legal solutions have delegated very few managerial competences to schools, so it is the incomplete school management that can be met in schools in Serbia rather than its developed form. However, a positive shift is that now schools themselves prepare their development plans.

It is not rational to introduce professional management in the majority of small and medium-size schools. They cannot rely only upon their own resources and capacities, even if all the teaching staff and pupils/students participate in decision making related to school development.

\section{Different approaches to defining the school management}

In theory and practice, there are still no precise defining and establishing of school management functions. In literature, there are various views on school governance and management. Bolman and Deal (1997:11) describe the "conceptual pluralism" in defining school management mostly as leadership vs. management. Halász (according to Bäckman/Trafford 2006), for instance, insists on differing school governing from school management; although these two concepts are closely related to each other, there are certain differences. While "governing" is used to stress the openness of schools and education systems, "management" is used to point out technical and instrumental 
dimensions of governance. In that respect various terms are used, such as governing, management, governing board, school leaders (Lalović 2010). There are also concepts like school management, management in education, educational management (Bush 2003), school-based management (Caldwell 2005; Malen et al 1990), management team, leadership (Mulford 2004), educational leaders, school leaders, educational administration (Dimmock 1999), etc.

In a wider sense, the concept of school management refers to overall work organization and managing the school in accordance with state law and policy. In a narrow sense, school management is defined through strategic and tactical development and operational plans. The school management defines the role and position of a school in local community, as well as staffing and school assets/finances policies (Lalović 2010:38). As Cankaya (2010) points out, a functional school management is based on five dimensions of school: people, places, program, processes and policies.

Over the last two decades, new approaches are evident in governing and managing the schools. Those approaches are the result of the state's new role towards administrative decentralization (Cadwell/Spinks 1988), as well as political decentralization (Fiske 1996).

In that respect, two strategies of school management are in focus: the "SchoolBased Management" (SBM) and the "New Public Management" (NPM). School-based management is the systematic decentralization to the school level of authority and responsibility to make decisions on significant matters related to school operations within a centrally determined framework of goals, policies, curriculum, standards, and accountability (Caldwell 2005:1). Malen et al (1990:290) point out that school-based management can be viewed conceptually as a formal alteration of governance structures, as a form of decentralization that identifies an individual school as a primary unit of improvement and relies on the redistribution of decision-making authority as the primary means through which improvement might be stimulated and sustained. Proponents of SBM assert that it increases communication among interest groups, including school boards, supervisors, head teachers, teachers, parents, members of the community.

The strategy of education decentralization is well-known as school-based management. Caldwell (2005:1) stresses the fact that school-based management means a systematic decentralization to the school level of authority and responsibility to make decisions on significant matters related to school operations within a centrally determined framework of goals, policies, curriculum, standards, and accountability. Proponents of the SBM concept state that it increases communication among the interest groups including school 
boards, supervisors, head teachers, teachers, parents, members of the community and students.

However, there are also doubts about the efficiency of school-based management. Firstly, it would be unrealistic to expect improvements in school results only basing on change in power relations within the present education system (Wohlstetter et al 1994). In addition, there are no empirical proofs of better educational results at schools operated on SBM principles (Summers and Johnson 1995). Secondly, the question is to whom in particular the state's governance should be redistributed (Oswald 1995), since the potential for development is limited by present conditions, primarily marked by fragmentized external control and the manager who is insufficiently involved in organization (Halász 2003).

Solutions to the mentioned issues have recently been derived from the theory and practice of new public management, a common title for a range of public sector reforms that have been introduced over the last 20 years in most of the OECD, developing and transitional countries in the world. The reforms are aimed at changing the role of state, from a leading subject of development to an agent and catalyser of the development process (Perko-Šeparoviæ 2002). The idea of good governance is based on the political concept of education reforms, introducing the private management methods into the public sector. New public management in education is gearing towards system decentralization, development of mechanisms of professional responsibility (standardization, tests and final exams, inspection), market mechanisms and more intensive involvement of local and regional community in school managing (Mulford 2003).

\section{Education system governance in Serbia}

School management decision-making authority and functions depend on the particular model of education system governance (Maroy 2004). That is actually a doctrinaire question of contemporary neoliberal and neoconservative politics, marked by insisting on government control over education curriculum, creation of shared curriculum, centralized pupils/students tests and rankings, etc. Numerous models of education system governance can be found in practice: the market model, school empowerment model, local empowerment model and quality control model (Glatter 2003); old and new public administration and organisational learning model (Mulford 2003); traditional and still dominant bureaucratic-professional model, quasi-market model and model of evaluative state, in which education goals and objectives are defined on the central level, but schools have a wide autonomy in their pedagogy practice and/or finances (Maroy 2004). 
Education system governance in Serbia can hardly be identified with any of these models; it is predominantly centralistic, clearly hierarchical on each of its four levels - the national, regional, municipal and school level. However, the key competences are kept on the first three levels. The Ministry of Education has its highest competences and empowerments as regards planning and monitoring the development of education; determination and delivery of funding and other resources (also administering the teachers' payrolls); planning, co-ordination and organization of educators' continual professional development; control of fulfilment of the aims and tasks set; issuing teacher and other educator certificates. On the regional, i.e. provincial level, it is the responsibility of the Provincial Secretariat for Education and Culture to define the school network, establish new secondary schools; adopt the curriculum and certify the schoolbooks/textbooks in ethnic minority languages; set up the school calendar; administratively control (secondary level) and govern school performance related to professional development, provision of quality education, data base maintenance, participation in preparing of education and upbringing development plan for the given area, and monitoring and reviewing progress.

Municipalities have legal capacity of: establishing/upgrading the primary schools network, basing on the criteria established on the national level; participating in their investment maintenance and supplying; administering control over school performance (municipal inspectorate), over educators professional development; establishing of school boards (Kovač-Cerović et al 2004).

Such a system of school governance can be considered close to the quality control model, i.e. centralized or rather directed model in which school acts as a "place providing educational services with the 'centre of gravity' in the central authority". Such a view is supported by the fact that by the 2009 regulations two parastatal bodies have been established: the first one is the National Educational Council (42 members, appointed by the Parliament, but strongly influenced by competing political parties) with duties in "monitoring, enhancing development, improving of quality of education and upbringing" (The Law on Grounds of Education System 2009, article 14). The second one is The Council for Professional Education and Education of Adults (21 members, appointed by the Government). In terms of functionality, this model is outdated to a great extent, so decentralization and de-politization of the education system should be directed towards the school-strengthening model.

Implementation of school management in Serbia will be, in the beginning, a complex and pioneering process, but it is a precondition for transformation of schools into modern, efficient and productive institutions. It will also mean liberation from unnecessary burdens in school programmes in order to improve school capacities for flexible and innovative transformations. This reform 
requires changes in school itself, then identification of all the important stakeholders (Shariff 2006), as well as changes in political, social and cultural interactions between school and its environment (Cheng/Chan 2000). However, a successful school management is only the one that develops such an organizational culture and school climate that make the following things possible:

- Partnership with students,

- Motivating students toward engagements and achievements,

- Recognizing students diversity,

- Stimulating students for individual engagement (to study and work - to work and study),

- Monitoring and assessment of students accomplishments,

- Educating creative personality,

- Continual adjustments of educational content and methods,

- Enhancing school's success and reputation.

\section{A view of the primary and secondary education systems in Serbia}

Out of 7,498,001 Serbian citizens according to the 2002 Census, children and the youth (ranging from kindergarten to university) make 1.2 million. Around 120,000 people work in educational institutions. Education is compulsory until the age of 16. Primary education begins at the age of 7 and lasts for 8 years, in two education cycles: four years of class teaching, followed by 4 years of subject teaching. Table 1 shows the number of students and teachers in secondary and primary schools. 
Table 1: Basic figures on elementary and secondary education in the Republic of Serbia (school year 2003-2004)

\begin{tabular}{|l|l|l|l|l|}
\hline & $\begin{array}{l}\text { Number of } \\
\text { schools } \\
\text { (including those } \\
\text { in peripheral } \\
\text { locations) }\end{array}$ & $\begin{array}{l}\text { Number of } \\
\text { classes }\end{array}$ & $\begin{array}{l}\text { Number of } \\
\text { pupils/students }\end{array}$ & $\begin{array}{l}\text { Number of } \\
\text { teachers }\end{array}$ \\
\hline Primary School & 3,587 & 31,174 & 667,570 & 44,791 \\
\hline $\begin{array}{l}\text { Secondary and } \\
\text { Grammar } \\
\text { Schools }\end{array}$ & 490 & 10,856 & 302,612 & 26,231 \\
\hline
\end{tabular}

Source: Ministry of Education and Sports of the Republic of Serbia, Statistics on elementary and secondary education in 2003-2004

Most of the schools are state schools; there are 5 certified private primary and 20 private secondary schools. Primary schooling covers about $95 \%$ of children, whereas secondary schooling covered $77.09 \%$ of the referent population in the school year 2004/5, with a $2.09 \%$ rate of early school leaving (Statistical Yearbook 2006).

State-funded education is free (non-fee paying), salaries and investments to state-funded schools are financed from the State budget, whereas maintenance, equipment and necessary adaptations to schools are locally financed. The costs of schoolbooks and other teaching material/resources as well as extracurricular activities, annual school excursions and school lunch are covered by parents; parents are often asked to financially contribute to school renovation.

Wide-scope longitudinal and transversal researches conducted between 2001 and 2008 were focused on indicators of teachers-pupils/students-parents relations (comprising 54 primary and secondary schools, 4710 pupils/students, 1411 teachers, 1056 parents; in: Ratkoviæ 2010; Kris-Piger 2004; Plačkov 2004; Vukelić 2004). According to the findings, the majority of teachers considered their position in society weak $(47.33 \%)$, or bad $(40 \%)$. Weakening of teachers' (educators on the whole) financial position has continued in recent years. The education budget at 5.3 per cent of gross domestic product/GDP is one of the lowest in Europe (as compared to the UNESCO recommended 6\%) of which $50 \%$ goes to salaries of primary and $55 \%$ to secondary schools employees. During 1990s, the educators' salaries fell drastically, averaging as low as \$1 per day in October 2000 literally at the edge of poverty (OECD, 
2001). At present, teacher salary averages around $\$ 300$ per month, which is still an insufficient income.

\section{Limitations to implementing school management in the Republic of Serbia}

Serbia has a sufficiently developed network of primary and secondary schools. However, the problem is that the network has not been reviewed for decades and does not respond to actual demographic, economic and social requirements. Over the last decade, this has caused intensive academic and other debates over education reform in the Republic of Serbia. It is generally agreed that the quality of education has declined: student knowledge is not functional, there are too many cases of repeating school year, negative attitudes to school are present ever more, the truancy rate and school dropout are increasing, and even risky behaviour is on the rise. It is in school where the curricula are the least discussed. There are also critical remarks on the crisis of pedagogy (Gojkov 2006): on the one hand, a strictly normative-legitimacy role of pedagogy is maintained, and on the other pedagogical pluralism and a search for authentic theoretical starting points of contemporary pedagogy are favoured. The topics are initiated concerning prospects of education as regards social justice. Here again Budrier's (1967) opinion has been confirmed that school education is not only an element of social mobility, but also of perpetuation of social inequalities. In Serbia, in 2002 for instance, $69 \%$ of the poor had the elementary 8 -year education or incomplete secondary education, while there was only $2 \%$ of the poor among those with higher education (Vuković 2006:18).

The study conducted by the Association of Teachers Colleges of Serbia (Factors and Indicators of Efficiency of Primary Education and Upbringing 1997) has investigated the present state of Serbian primary schools, their compatibility with European schools and their future prospects. Its findings indicate that the teaching process has not been organized as a complete process, since the feedback is missing. School pedagogy is based more on an entropic approach than on a systems approach, and that is reflected in the traditional model of pedagogical levelling. The outcome is that by the end of a class "children don't know what they've been taught, and the teachers don't have the idea of their pupils' knowledge" (Vilotijević 1997:40). The OECD/PISA surveys of the student knowledge and skills for the years 2003, 2006 and 2009 have shown poor performance of Serbian pupils, which was below the European average: almost a third of them are functionally illiterate, and have problems with applying their knowledge to practice. ${ }^{8}$

8 Some domestic analysts have explained the bad test results of Serbian pupils and students by incompatibility of Serbian education system with those in the EU countries, and by the fact that Pisa tests are focused on functional and not on encyclopedic knowledge. 
The need for improvement of the Serbian educational system is well illustrated by low education structure of Serbian population. According to the 2002 Census, $11 \%$ were highly educated (6.5\% university level), $41 \%$ had secondary level diploma, almost $24 \%$ had only finished the 8 -year primary school, whereas as many as $20 \%$ had neither finished primary school; about $5 \%$ of children had never entered any school, in rural areas even more - about $20 \%$. There are no reliable data on schooling of the disabled or Roma children, but some NGOs state that in some of the special schools for disabled and special needs over $80 \%$ are Roma children and $65 \%$ of rural population have no vocational let alone academic education at all.

As reported by the National Education Council of the Republic of Serbia (2011:19), almost 10\% of the young people, age between 18 and 24, leave school before finishing secondary education. They take no other courses or professional training. Nearly $85 \%$ of those at the age of $20-24$ have finished secondary school education. An increase by $15 \%$ is reported in the number of those who have graduated from mathematics, sciences and technology; among these graduates, males outnumber females to a smaller extent than earlier.

On top of this come the pressures from the World Bank (2009) to rationalize cut down the number of schools by 11.000 that have insufficient number of pupils. Such a requirement affects rural primary schools in particular, where in the so-called combined class's curricula of 2, 3 or even 4 years are taught simultaneously. There are about 3,000 such schools, averaging 9.8 pupils. Cutting down of such schools would cause great social issues - more jobless teachers, endangered rights of some ethnic minorities in multiethnic communities, reduced chances for schooling to children living in remote areas. This all would even worsen the already bad education structure of rural population: $36.3 \%$ of rural population in Serbia have not even finished the 8year primary school - as reported by the Serbian Academy of Science and Arts (2009).

It is clear that these problems cannot be resolved by introducing modern school management alone, but that certainly is one of the ways to make the school education more efficient. There are, however, numerous limitations. Three major factors limiting the implementation of school management are discussed further below.

\section{High degree of State's administrative governance}

High extent of State influence in school governance, even in operating the schools, has limiting effects on school management, regardless of the position and type of school leader. In most schools, the management role is performed by the head teacher, either him alone or with his assistants. He is in a sort of a "sandwich" position (Lalović 2010) and has to balance between the higher governing and state bodies (Ministry of Education, Education Inspectorate, 
Regional Department for Pedagogy, School Board, Parents Council) on the one side, and the needs and requirements of school employees, on the other. In that sense, Halász (2003) states that it is impossible to operate the school in a responsible and efficient manner if the interventions arrive all the time from external, mostly political agents. In such a situation teachers are "a group of civil servants and an integral part of state-controlled public administration" (Gozzer 1991:16) who had not managed to get professionally organized before the State intervened into the schooling system.

The administrative way of governing the schools is exclusively based on school inputs, like number of programs, pupils, teachers, teaching hours, property, amortization and other input variables that are used in assessing the education costs structure. The most obvious parameters alone are persistently used, and the conclusions derived are consequently not reliable: more teachers - more education, more school hours - more knowledge, more exams passed - higher achievement. These all do not contribute to such an allocation of resources that would be in accordance with the quality of work at schools.

This was also the topic of the regional conference on Democratic School Operating (Belgrade, 27-29 January 2010; in: Demokratsko građanstvo 2010, 910). It was argued that Serbia sustains the education system, which is directed and centralized, in which a school's structure is not a democratic one. Political decisions and everyday politics have major influences on schools. However, there are "some sprouts" of institutions within the schooling system that could become participants in the intra-school dialogue, such as students' parliament which will make it possible for the students voice to be heard. A more active role of other institutions is necessary to make the voice of parents and the interests of local community heard. The aim is to change schools so that they could change the society in a democratic sense. These processes are supported by the reform of school self-management, which has already begun and is closely associated with the strengthening of regional and local self-government, but only if the role of the medium-level governance is clearly defined, the one between the national (state) and local (municipality) levels (Miljević 2003).

\section{Insufficient cooperation between school and parents}

Insufficient cooperation with parents has numerous reasons, the most apparent being parents' apathy and the lack of interest, but also the educators' fear of losing professional autonomy (Stanković 2006). These findings comply with the mentioned researches (Ratković 2010; Kris-Piger 2004; Plačkov 2004; Vukelić 2004). As stated by $75 \%$ of parents surveyed, the co-operation between parents and school is rather poor; within one particular class $55 \%$ of parents said it was successful and $45 \%$ that it was unsuccessful (Kris-Piger 2004). Teachers' answers also expressed a relative diskontent with co-operation with parents: $82.5 \%$ assessed it as medium, $7.5 \%$ as unsatisfying and only $10 \%$ as very good. 
The results are somewhat better regarding individual co-operation of parents and teachers: $32.5 \%$ of teachers surveyed found it to be successful, $62.5 \%$ medium and 5\% unsuccessful (Kris-Piger 2004).

Domestic regulations (The Law on Grounds of Education System 2009) on parents' participation in governing the elementary and secondary schools comply with the European trends. Parents can use the legally guaranteed opportunity to govern the school through involvement in the work of School board and Parents council. However, the majority of them are still not conscious of the importance of their own role for schools to operate successfully, and they are still uninformed about the regulations and rules that provide the framework for their more active involvement.

\section{Teachers doubts and fears}

The third limiting factor is the opinion, deep-rooted in many $(60 \%)$ teachers minds (Ratković 2010) that the management system is only necessary for a profitable business. These teachers consider it a techno-bureaucratic, cold and impersonal relationship, "reserved for" the economic sphere alone, and that managerism is incompatible with values and content of education. Hierarchical organization of work and vertical responsibility cause distrust, discontent and inequality among educational employees (Staničić 2006). Managers are considered to exert undue pressure on their staff and to use power immorally, in order to achieve the organization's goals.

\section{Non-compliance of present state of school management with the requirements of modern education}

There are many indicators of unsatisfying situation in governing the school, inadequate to modern education objectives and tasks. Here are some of the still relevant findings of the research studies on school planning and governing, conducted between 1992 and 1997 (on the total sample of 1227 head teachers, their assistants, pedagogical consultants and school secretaries, in elementary and secondary schools in the republic of Serbia and the Republic of Montenegro (Direktor škole 3/1995; Archives of the Teachers Faculty, Belgrade 19931997):

- School planning and managing do not comply with the needs of modern education;

- School planning and managing do not contribute to developing schools into efficient systems;

- They are more formally adopted than efficiently practised;

- Personal capacities, financial means and property are not clearly defined; 
- Planned tasks are either too broad and too ambitious or too narrow and unambitious;

- There is no planned interaction between school and its community environment. ${ }^{9}$

With respect to these issues a conclusion can be made that basic questions and dilemmas on school management are still unanswered: what is specific about management in education; how should the relationship between state and education system be regulated; how should education process and resources be managed; what should be the obligations of a school manager; what are the mechanisms for providing financial resources to be used for management? Another few issues have also not been addressed so far: financial aspects of education; marketing in education; fundraising through projects that provide money for improving the education process.

\section{Research}

\section{Research problem and objectives}

Since 2009 in the Republic of Serbia, schools have been given the autonomy in defining their multi-annual development plans, in which activities are defined, and the criteria and measures for assessing the fulfilment of planned tasks (evaluation). The education policy shift towards school management is also manifest in the increased significance of school development plans, as already reported earlier in literature (Hargreaves/Hopkins 2003; Cheng 2001b, 1996; Caldwell/Spinks 1998; Stringfield et al.1996; Murphy/Beck 1995; MacGilchrist et al. Savage/Beresford 1995; Reynolds/Cuttance 1992). Since planning at present is the only euthentic school management function in Serbian schools (apart from standard managerial ones) this research was aimed at investigating the relationships among planning and organizing, managing and evaluation of school performance. In that respect, the attention has also been paid to work quality assurance, realization of school development plan as well as rationality and organization of the teaching process.

\section{The participants}

The participants were recruited among the employed in all the 12 primary and secondary schools in a chosen municipality with the population of 70,000 . These 12 schools have in total 312 classes with 7,210 students and 564 teachers. The sample included 12 school head teachers, 341 teachers and 16 psychologists and pedagogy consultants (i.e. non-teaching specialists), in total 369 employees. Gender structure was much in favour of women: $77 \%$ female

9 The research study was conducted by the Centre for Education Managers Professional Skills Extending - CURO of the Teachers Faculty in Belgrade, Serbia. 
and $23 \%$ male participants. Almost the same were numbers of those with work experience of 10 to 20 years and those of 20 to 30 years, together accounting for around $55 \%$ of all the participants. About $17 \%$ of participants had less than 5 years of work experience, 5-10 years 12.3 and over 30 years $15.7 \%$. Age of participants ranged from 21 to 64 , averaging 44 years and 8 months.

\section{Measurement instruments}

Four separate questionnaires were designed for the survey, with closed response questions (mostly 1-5 interval scale measuring respondent's agreement with the question statement).

The first questionnaire, distributed to head teachers, has 3 subscales:

- "Planning" (15 questions), in which the variable "Work planning" was operationalized;

- "School managing" (12 questions) in which the variable "Organizing and operating the school" was operationalized. This subscale refers to school management;

- "Monitoring and evaluation" (18 questions) in which the variable "Monitoring and evaluation" was operationalized. This subscale refers to all the employed as well as to pupils/students.

The second questionnaire, distributed to teachers, has 3 subscales:

- "Planning of teaching process" (8 questions), in which the variable "Planning of teaching" was operationalized;

- "Preparing for teaching" (14 questions) in which the variable "Preparation for teaching" was operationalized;

- "Rationality and lecture organizing" (8 questions) in which the variable "Rationality and organization of teaching" was operationalized.

The third questionnaire, distributed to all the employed, has 2 subscales:

- "Providing of quality" (15 questions), in which the variable "Providing quality school performance" was operationalized;

- "School development plan" (14 questions) in which the variable "School development plan" was operationalized.

The fourth questionnaire, distributed to psychologists and pedagogy consultants consisted of 10 statements in which the variable "Realization of school development plan" was operationalized. 


\section{Variables}

The independent variables covered school staff (head teachers, teachers, psychologists and pedagogy consultants) and four aspects of school management (planning, organizing, managing and monitoring and evaluation of work in schools). The dependent variables were the participants' assessments on questionnaire subscales (one for each of the 3 subgroups). The following demographic characteristics were recorded: gender, age, school in which the respondent was employed, position and work experience.

\section{Realization of Survey}

The research was conducted in the first half of June 2009. The participants were asked to fill in the questionnaire within 30 minutes.

\section{Key characteristics of the respondents}

\section{Head teachers}

Among 12 head teachers 3 (25\%) were women and 9 (75\%) men, age 50 on the average. Seven of them $(58.3 \%)$ were from primary schools, $3(25 \%)$ from secondary schools and only one (8.3\%) from the school for the disabled children. Of all the head teachers participating in the research $60 \%$ had the work experience of $20-30$ years, $25 \%$ had $10-20$, and the share of those with work experience 5-10 years was identical as those over $30(8.3 \%)$.

\section{Teachers}

The majority of 341 teachers were women, $266(78 \%)$ and 74 men accounted for $21.7 \%$. The average age was 43 . Long working experience prevailed: $30 \%$ of participants had 10-20 years of work experience, and 26\% had 20-30 years. Teachers with less than 5 years accounted for $16.7 \%$ and those with more than 30 years $-16 \%$. Most of the respondents, $240(70.4 \%)$ work at elementary schools; $79(23.2 \%)$ work at secondary schools and $13(3.8 \%)$ at schools for the disabled children. These figures match the number of schools included (7 primary schools, 3 secondary and 1 for the disabled children).

\section{Non-teaching specialists}

All the 16 respondents, school psychologists or pedagogy consultants, were female, age 46 on the average. Most of them, 9 (56.2\%) had 20-30 years work experience, followed by 4 (25\%) with 5-10, and $3(18.8 \%)$ had $10-20$ years of work experience.

\section{Data processing}

The data collected were processed with SPSS statistical software package, providing: 
- Descriptive statistical indicators for the variables (frequencies, percentage, mean, and standard deviation);

- Association between variables was checked using Pearson's Correlation on summary scores for subscales in the questionnaire.

\section{Empirical findings}

School staff

The respondents in this sub-sample were answering the questions on provision of quality of the school development plan. Average values (arithmetic mean) were calculated for each scale summary score. Maximum total score for both scales was 75. The average score on the subscale "Provision of quality" was 50 points, meaning that the respondents considered it to be mostly good, while the average score on the subscale "School development plan" was 54, meaning that the respondents valued its importance somewhat higher. As for the respondent demography, "Provision of quality" was valued higher by male than by female respondents; age and years of work experience were not significant in that respect.

\section{Head teachers}

Head teachers filled in the questionnaire with 3 subscales: "School operational planning", "Organizing and managing" (school management) and "Monitoring and evaluation of school operation". Maximum total score for the "Planning" subscale was 27; only one respondent had the lowest score (18) and the highest score was 25; on the average, head teachers' assessment of work planning at their school was $M=21.5$. Of the maximum total score of 20 points on the subscale "Organizing and managing" the lowest one was 12, the highest 18, mean value being $M=14.7$. Maximum total score for the "Monitoring and evaluation" subscale was 27 , the lowest individual score 20 , the highest one 27 , and the average score on this scale was $M=21.9$. This shows that, according to head teachers' assessments, work planning as well as the very head teachers' activities are of a satisfying level. However, planning on lower levels was not graded as satisfying, since only $58.3 \%$ of head teachers and their collaborators make weakly and monthly work plans; the same proportion of them make daily plans if needed, whereas $33.3 \%$ have a detailed plan for each particular day.

Association between planning and monitoring and evaluation was analyzed using Pearson's Correlation, on summary scores of each of the three scales for head teachers (Table 2). The results show that school operation planning correlates significantly with monitoring and evaluation and with organizing and managing (management) as well. Monitoring and evaluating of school operation (staff's work, pupils/students achievements, etc.) correlates significantly with organizing and managing. 
Table 2: Correlations between pairs of subscales in the questionnaire for head teachers

\begin{tabular}{|l|c|c|}
\hline Questionnaire subscale pairs & $\mathrm{r}$ & $\mathrm{p}$ \\
\hline $\begin{array}{l}\text { Planning and monitoring with } \\
\text { evaluation }\end{array}$ & .236 & .011 \\
\hline $\begin{array}{l}\text { Planning and organizing with } \\
\text { managing }\end{array}$ & .464 & .050 \\
\hline $\begin{array}{l}\text { Monitoring and evaluation with } \\
\text { organizing and managing }\end{array}$ & .337 & .017 \\
\hline
\end{tabular}

Correlations significant with the significance level of .05

These participants responded to questions referring to management, planning, preparing, rationality and organization in teaching. The subscale "Planning" had 40 points at maximum $(\mathrm{M}=31.75, \mathrm{SD}=5.03)$, meaning that planning is mostly assessed as good. The subscale "Preparing" had a maximum of 40 grades $(M=$ $31.75, S D=5.03)$, meaning that „Planning” is mostly assessed as „Good”. The subscale "Preparing" had 14 items and a maximum of 70 grades $(M=57.06, S D$ $=8.49$ ). In the subscale "Rationality with Organization" the maximum grade was $40(M=35.09, S D=3.94)$. Relations among variables were checked by using Pearson's coefficient of linear correlation on subscale total scores (Table 3).

Table 3: Correlations between subscales in the questionnaire for teachers

\begin{tabular}{|l|c|c|}
\hline $\begin{array}{l}\text { Pairs of questionnaire } \\
\text { subscales }\end{array}$ & $\mathrm{r}$ & $\mathrm{p}$ \\
\hline Planning and preparing & .714 & .000 \\
\hline $\begin{array}{l}\text { Planning and rationality } \\
\text { with organization }\end{array}$ & .674 & .000 \\
\hline $\begin{array}{l}\text { Preparing and rationality } \\
\text { with organization }\end{array}$ & .737 & .000 \\
\hline
\end{tabular}

The results show statistically significant correlations of all the subscales; all correlations are strong and with positive coefficients. There are statistically significant correlations between subscales "Planning with Preparing" as well as between "Planning" and "Rationality with organizing". This means that the more evident planning is, the more evident are preparing, rationality and organization in teaching. As for the interrelation of "Preparing" and 
"Rationality", it is also strong and as the values on the one subscale rise, the values on the other do as well.

\section{Non-teaching specialists}

The participants responded to questions about the realization of the school development plan. The lowest individual mark out of the maximum of 30 grades in the questionnaire, the lowest grade was 16 , given by only one female respondent; the highest grade was 27 . On the average $(M=23)$ the non-teaching specialists' estimation is that the realisation of the school development plan is good.

\section{Conclusions}

In Serbia, implementation of school management is still at the stage of concept discussing; however, initial attempts have been made in schools where more rational and efficient managing is necessary. Among the obstacles to developing all the school management functions the major ones are: highly centralized government administration of schools, poor co-operation between school and parents, teachers' doubts and fear of changes.

Since 2009 schools in Serbia have been delegated the legal capacity to create by themselves their development plans for three to five years, which is one of the most important preconditions for implementation of school management. The right to define school development plans brings to schools a new role and new responsibilities; development planning has to correspond to school development goals as agreed among all the interest groups.

Although school development planning is a novelty in Serbian schools, the results of this survey have shown that it is highly valued by unexpectedly great majority of respondents. They see the development plans as a driving force to significant improvements and as an opportunity for themselves as educators to be initiators and agents of significant changes in school managing. However, the survey has also shown that the opportunity to plan school development has only reluctantly been made use of in terms of tailoring a plan to express school's authentic profile and needs. Almost half of the interviewed managers expressed a rather normativistic approach to development planning so that in the great majority of plans there is no trace of school's authentic needs, let alone the proposed solutions for meeting them. The key obstacles to creating such school development plans that would be the base for positive qualitative changes in school life are insufficiently developed teamwork, only partially defined roles and responsibilities, and the lack of effective participation/involvement of parents and local community.

Although evaluation of the development plan realization (review and selfassessment) is necessary for measuring school's success in delivering activities 
and achieving targets, this survey results indicate that evaluation is the school's weakest link. In almost all the schools surveyed their management teams deal with teachers' work evaluation and assessment of students'/pupils' achievements only at the end of a school year. This can be attributed to the inefficient system of internal control, but even more to head teachers' inertia and the surviving practice of government commissions performing control and assessment.

At present, school management has not been implemented to its fullest potential in any of the schools in this survey, regarding school managing, organizing and operating. School management has not yet developed all its functions and as many as $80 \%$ of participants in our survey consider it to be inefficient.

\section{References}

Archives of the Teachers Faculty 1993-1997, Belgrade. Belgrade: Učiteljski fakultet [Teachers Faculty].

Bäckman, E. / Trafford, B. (2006): Democratic Governance of Schools. Strasbourg: Council of Europe.

Bolman, L./ Deal, T. (1984): Modern approaches to understanding and managing organizations. San Francisco: Jossey Bass.

Burdije, P. (1967): Škola kao zaštitnik nejednakosti [School as a protector of inequalities], in: Gledišta, 2, 263-277.

Bush, T. (2003): Theories of educational management, Third Edition. London: Sage.

Caldwell BJ (2005): School-based management. UNESCO: The International Institute for Educational Planning (IIEP).

Caldwell, BJ/ Spinks, JM. (1988): The Self-Managing School. London: Falmer Press.

Cankaya IH (2010): School managers' views about school safety from the invitational theory perspective, in: African Journal of Business Management, 4, 12, 2415-2423.

Cheng, YC (2001b): Educational Relevance, Quality and Effectiveness: Paradigm Shifts. Invited keynote speech to be presented at the International Congress for School Effectiveness and School Improvement held in 5-9 January 2001 in Toronto, Canada, with the theme "Equity, Globalization, and Change: Education for the 21 st Century".

Cheng YC (1996): A school-based management mechanism for school effectiveness and development, in: School Effectiveness and School Improvement, 7, 1, 35-61.

Cheng YC/ Chan MT (2000): Implementation of school-based management: A multiperspective analysis of the case of Hong Kong, in: International Review of Education, 46, 3-4, 205-232. 
Činioci i indikatori efikasnosti i metode unapređivanja osnovnog obrazovanja vaspitanja. Zbornik radova sa simpozijuma „Činioci i indikatori efikasnosti i metode unapređivanja osnovnog obrazovanja i vaspitanja", Zlatibor, 28, 29, i 30. oktobar [Factors and Indicators of Efficiency of Primary Education and Upbringing. Proceedings from the symposium "Factors and indicators of efficiency and methods of improving primary education ans upbringing"] (1997). Belgrade: Zajednica učiteljskih fakulteta Srbije [Association of Teachers Faculties of Serbia].

Demokratizacija škole - preduslov demokratskog društva [Democratization of School Precondition for a Democratic Society] (2010): in: Demokratsko građanstvo, 9/10, 78.

Dimmock, C. (1999): Principals and school restructuring: Conceptualising challenges as dilemmas, in: Journal of Educational Administration, 37, 5, 441-462.

Fiske, EB (1996): Decentralization of Education: Politics and consensus. Directions in Development. Washington DC: World Bank.

Glatter, R. (2003): Models of governance and their implications for autonomy, accountability and leadership; in OECD, Networks of innovation, 66-84. Paris: OECD.

Gojkov, G. (2006): Didaktika i postmoderna [Didactics and Postmodernism]. Vršac: Viša škola za obrazovanje vaspitača [The Teacher Training College].

Gozzer, G. (1991): Školski programi i društveni problemi [School Curricula and Social Issues], in: Nedeljković, Č. (Ed.), Putevi obrazovanja - strana iskustva [Milestones in Education - International Practices]. Belgrade: Saša Nedeljković.

Halász, G. (2003): Reforma obrazovanja i upravljanje obrazovanjem na regionalnom nivou u Srbiji (Neredigovan nacrt) [Educational Reform and Educational Management on Regional Level in Serbia (Unproofed draft)]. Budapest: National Institute of Public Education. Available at: http://www.see-educoop.net/education_in/pdf/educ-ref-reglev-educ-admin-yug-srb-ser-t05.pdf (accessed 6 April 2011).

Hargreaves, DH/ Hopkins, D. (2003): Škola može više - menadžment i praksa razvojnog planiranja [School Can Do More - Management and the Practice of Developmental Planning]. Ljubljana: Zavod za školstvo.

Indicators for monitoring the Education (2011). Belgrade: National Education Council of the Republic of Serbia.

Kovač-Cerović, T. et al (2004): Quality education for all: challenges to the education reform in Serbia. Belgrade: The Republic of Serbia, Ministry of Education and Sports.

Kris Piger, J. (2004): Odnos učenik - nastavnik - roditelj u srednjoj školi [Relationship pupil teacher - parent in Secondary School]. Novi Sad: Misao.

Lalović, RR (2010): Upravljanje i rukovođenje u školi [Management and Operating the School], in: Direktor škole, 1, 29-40.

MacGilchrist, B./ Mortimore, P./ Savage, J./ Beresford, C. (1995): Planning matters: The impact of development planning in primary schools. London,UK: Paul Chapman Publishing Ltd. 
Malen, B./ Ogawa, RT/ Kranz, J. (1990): What Do We Know about Site-based Management: a Case Study of the Literature - A Call for Research, in: Clune, WH / Witte, JF (Eds.), Choice, and control in American education, 2: The practice of choice, decentralization, and school restructuring. London: Falmer Press, 289-342.

Maroy, Ch. (2004): Regulation and inequalities in European education systems. Available at: http://www.pjb.co.uk/npl/bp63.pdf (accessed 18 July 2011).

Miljević, G. (2003): A brief tour through the education system reform in the Republic of Serbia. Available at: http://www.see-educoop.net/education_in/pdf/edutour2001-03ser-yug-srb-t05.pdf (accessed 6 April 2011).

Mulford, B. (2004): Leadership for school and student learning, in: Independence, 29, 2, 3435.

Mulford, B. (2003): School Leaders: Changing Roles and Impact on Teacher and School Effectiveness. Paris: Education and Training Policy Division, OECD.

Murphy, J./ Beck, L. (1995): School-based Management as School Reform. Thousand Oaks, CA, Corwin Press.

OECD (2010): PISA 2009: Results: Executive Summary. Paris.

OECD (2007): PISA 2006: Science Competencies for Tomorrow's World, 1. Paris.

OECD (2005): PISA 2003: Technical Report. Paris.

Oswald, LJ (1995): School-based management. ERIC Digest [Online]. Available at: http://eric.uoregon.edu/publications/digests/digest099.html (accessed 4 April 2011).

Perko-Šeparoviæ, I. (2002): Novi javni menadžment - britanski model [New Public Management - British Model], Politièka misao, XXXIX, 4, 31-43.

Plačkov, D. (2004): Udruženi nastavnici, učenici i roditelji [United teachers, pupils, and parents]. Novi Sad: Misao.

Program stručnog usavršavanja direktora i stručnih saradnika osnovnih i srednjih škola [Programme of Professional Improvement of Head Teachers and Teaching Staff in Primary and Secondary Schools] (1995): in: Direktor škole, 3, 91-98.

Ratković, M. (2010): Put ka uspešnoj školi [Towards a Successful School]. Novi Sad: Prometej.

Reynoldsn, D./ Cuttance, P. (1992): School effectiveness Research Policy and Practice. London: Cassell.

Shariff, Sh. (2006): Balancing Competing Rights: A Stakeholder Model for Democratic Schools, in: Canadian Journal of Education, 29, 2, 476-496.

Serbian Academy of Arts and Sciences, Board of Education (2009): Education of rural people. Scientific conference held on 12 November 2009, Belgrade. Available at: http://www.sanu.ac.rs/odbor-obrazovanje/Informacije/zakljucciIpreporuke.pdf (accessed 20 July 2011).

Stanković, D. (2010): Upravljanje sistemom obrazovanja: međunarodni trendovi i glavne teme [Management of Education System: international trends and major topics], in: Zbornik Insistuta za pedagoška istraživanja [Journal of the Institute for Educational Research], 42, 1, 42-55. 
Statistics on Elementary and Secondary Education 2003/2004. Belgrade: Ministry of Education and Sports of the Republic of Serbia.

Statistical Yearbook (2006): Belgrade: Statistical Office of Serbia.

Stringfield, S./ Ross, S./ Smith, L. (eds.) (1996): Bold plans for school restructuring: The New American Schools designs. Mahwah, NJ: Erlbaum.

Summers, AA/ Johnson, AW (1995): Doubts About Decentralized Decisions, in: School Administrator, 52, 3, 24-26, 28, 30, 32.

The Law on Grounds of Education System (2009): Belgrade: Official Gazette of the Republic of Serbia, 79.

The World Bank (2009): Serbia - Doing more with less : addressing the fiscal crisis by increasing public sector productivity, Report No. 48620-YF.

Vilotijević, M. (1997): Modelovanje kompleksnog sistema vrednovanja rada škole [Modelling a Complex System of School Performance Evaluation], in: Činioci i indikatori efikasnosti i metode unapređivanja osnovnog vaspitanja i obrazovanja. Zbornik radova sa simpozijuma „Činioci i indikatori efikasnosti i metode unapređivanja osnovnog vaspitanja i obrazovanja", Zlatibor, 28, 29, i 30. oktobar [Factors and indicators of efficiency and methods of improving primary education. Proceedings from the Symposium "Factors and indicators of efficiency and methods of improving primary education"] (1997). Belgrade: Zajednica učiteljskih fakulteta Srbije [Association of Teachers Faculties of Serbia], 20-41.

Vukelić, M. (2004): Domovi učenika srednjih škola i odnosi učenik - vaspitač - nastavnik roditelj [Secondary School Boarding Houses and the Student - Teacher - Parent Relations]. Novi Sad: Misao.

Vuković, S. (2006): Strategija za smanjenje siromaštva u obrazovanju dece [Strategy for Reduction of Poverty in the Education of Children], in: Naučni skup sa međunarodnim učešćem „Saradnja škole i porodice” (Rezimei, p. 18) [Scientific conference with international participation "Co-operation of School and Family" (Abstracts, p. 18)]. Belgrade: Institut za pedagoška istraživanja [Institute for Pedagogical Studies].

Wohlstetter, P./ Smyer, R. / Albers Mohrman, S. (1994): New Boundaries for School-Based Management: The High Involvement Model. Paper presented at the Annual Meeting of the American Educational Research Association, New Orleans, Louisiana. 